The Bangladesh Veterinarian (2017) 34(1): 61 - 70

\title{
Comparison of meat yield and quality characteristics between indigenous chicken and commercial broiler
}

\author{
N Farzana, M Habib ${ }^{1}$, MH Ali, MA Hashem² and MS Ali* \\ Department of Poultry Science, Faculty of Animal Husbandry, Bangladesh Agricultural \\ University, Mymensingh-2202, Bangladesh
}

\begin{abstract}
Yield and quality of meats from commercial broiler and indigenous chickens weighing one $\mathrm{kg}$ each were studied during different periods of refrigeration. The chicken carcasses were stored at $-20^{\circ} \mathrm{C}$ for 30 days and were analyzed on 0,15 and 30 days. Carcass weight $(\%)$, shank weight $(\%)$, dressing $(\%)$, breast meat yield $(\%)$ were higher $(\mathrm{P}<0.05)$ in commercial broilers, but head $(\%)$, neck $(\%)$, thigh meat $(\%)$, drumstick meat $(\%)$ were higher $(\mathrm{P}<0.01)$ in indigenous chickens. Shank weight $(\%)$ decreased with storage time. Higher $(\mathrm{P}<0.01)$ percentage of dry matter $(\mathrm{DM})$ and crude protein $(\mathrm{CP})$ were found in indigenous chicken breast meat, while ether extract (EE) and total ash content were higher $(\mathrm{P}<0.01)$ in commercial broiler breast meat. Cooking loss $(\%)$ was higher in commercial broiler breast meat. The $\mathrm{pH}$ and $\mathrm{CP}(\%)$ decreased, while DM (\%), EE (\%), Ash (\%), Thiobarbituric acid reactive substance (TBARS) value, free fatty acid (FFA) value, and Peroxide value (POV) increased with storage time in both types of chicken. Sensory evaluation showed more juiciness in commercial broiler meat. (Bangl. vet. 2017. Vol. 34, No. 2, $61-70)$
\end{abstract}

\section{Introduction}

Genetic selection for rapid growth rate has engineered the commercial broiler chickens to the extent that they may have several undesirable characteristics such as excess deposition of adipose tissue, and inability to tolerate the stress of climatic insults and mismanagement. Broiler carcasses contain high fat, less protein and higher cholesterol (Mendes et al., 1994), while indigenous chickens are widely preferred by consumers because of their lean meat, less fat and cholesterol with more protein, taste, pigmentation and suitability for special dishes (Islam and Nishibori, 2009). Poultry meat quality is affected by lipid oxidation during storage. Delaying lipid oxidation is relevant to the poultry processors as well as consumers. Oxidative processes in meat lead to the degradation of lipids and proteins which, in turn, contribute to the deterioration in flavor, texture and color of meat products (Decker et al., 1995).

The present study was carried out to compare the meat yield characteristics, physicochemical, biochemical and sensory properties of meat from native and commercial broiler chicken of similar body weight at different storage times.

${ }^{1}$ Graduate Training Institute, Bangladesh Agricultural University, Mymensingh-2202, Bangladesh 2Department of Animal Science, Bangladesh Agricultural University, Mymensingh-2202, Bangladesh *Corresponding author:- E-mail: mdshawkatali@hotmail.com 


\section{Materials and Methods}

Commercial broilers at $1000 \pm 50 \mathrm{~g}$ live weight were purchased from Bangladesh Agricultural University Poultry Farm, while the indigenous chicken at similar weight were bought from local market. All birds were weighed before and after slaughtering, bled, plucked and eviscerated. The carcasses were stored at $-20^{\circ} \mathrm{C}$ for 30 days and breast meat was analysed at 0,15 and 30 days.

\section{Proximate compositions}

Proximate composition of DM, EE, CP and Ash were carried out with standard procedures $(A O A C, 2005)$ in triplicate, and the mean values were calculated.

\section{pH determination}

The $\mathrm{pH}$ of raw breast meat homogenate was determined by blending $10 \mathrm{~g}$ of sample with $50 \mathrm{~mL}$ of distilled water using an Ultra Turrax T25 tissue homogenizer (Janke and Kunkel, IKA Labortechnik, Staufen, Germany) at 8,000 rpm for one min. The $\mathrm{pH}$ of the suspension was recorded by dipping combined glass electrode of Elico digital pH meter, Model LI 127 (Elico Limited, Hyderabad, India).

\section{Cooking loss}

To determine cooking loss, weighed $5 \pm 1$ gm samples were wrapped in a heat-stable foil paper and kept in water bath at $80^{\circ} \mathrm{C}$ for $30 \mathrm{~min}$. Samples were surface-dried and weighed. Cooking loss was calculated after draining the drip coming from the cooked meat as the percentage loss of weight of the cooked sample (Symeon et al., 2010).

Cook loss $(\%)=\left[(w 2-w 3) \_w 2\right] \times 100$;

where, w2 = meat weight before cooking and w3 = meat weight after cooking.

\section{Thiobarbituric acid reactive substance (TBARS) analysis}

Lipid oxidation was assessed in triplicate using the 2-thiobarbituric acid (TBA) method as described by Schmedes and Holmer (1989). Chicken breast meat samples $(5 \mathrm{~g})$ were blended with $25 \mathrm{~mL}$ of $20 \%$ trichloro acetic acid solution $(200 \mathrm{~g} / \mathrm{L}$ of trichloro acetic acid in $135 \mathrm{~mL} / \mathrm{L}$ phosphoric acid solution) in a homogenizer (IKA) for $30 \mathrm{sec}$. The homogenized sample was filtered with Whatman filter paper number 4 , and $2 \mathrm{~mL}$ of the filtrate was added to $2 \mathrm{~mL}$ of $0.02 \mathrm{M}$ aqueous TBA solution $(3 \mathrm{~g} / \mathrm{L})$ in a test tube. The test tubes were incubated at $100^{\circ} \mathrm{C}$ for $30 \mathrm{~min}$ and cooled with tap water. The absorbance was measured at $532 \mathrm{~nm}$ using a UV-VIS spectrophotometer (UV-1200, Shimadzu, Japan). The amounts of TBARS were expressed as milligrams of malonaldehyde per kilogram of meat.

\section{Free fatty acid analysis}

Free fatty acid value (FFA) was determined according to Rukunudin et al. (1998). Five gm of sample was dissolved in $30 \mathrm{~mL}$ chloroform using a homogenizer (IKA T25 digital Ultra-Turrax, Germany) at $10000 \mathrm{rpm}$ for one min. The sample was filtered 
under vacuum through Whatman filter paper number 1 to remove meat particles. Five drops of $1 \%$ ethanolicphenolphthalein were added as indicator to filtrate, and the solution was titrated with $0.01 \mathrm{~N}$ ethanolicpotassium hydroxide.

FFA $(\%)=m L$ titration $\times$ Normality of $\mathrm{KOH} \times 28.2 / \mathrm{gm}$ of sample

\section{Peroxide value (POV)}

Peroxide values of the samples were determined according to AOAC (2005). One gm of sample was accurately weighed into $250 \mathrm{~mL}$ conical flask. Thirty $\mathrm{mL}$ of a mixture of glacial acetic acid and chloroform $(3: 2)$ were added to the conical flask. One gm of saturated solution of potassium iodide was added and the flask was vigorously shaken for one min. and kept away from the light for exactly $5 \mathrm{~min}$., then titrated with accurately standardized solution of $0.01 \mathrm{~N}$ sodium thiosulphate. Titration continued until the yellow colour almost disappeared. A $0.05 \mathrm{~mL}$ of starch indicator solution was added. Titration was performed with continuous shaking till the end point. Drops of thiosulphate were added until the blue colour disappeared. POV was calculated from $\mathrm{POV} \%=\{(\mathrm{A}-\mathrm{B}) \times \mathrm{N} \times 100\} / \mathrm{S}$.

Where; $\mathrm{B}=$ reading of blank in $\mathrm{ml}, \mathrm{A}=$ reading of sample in $\mathrm{ml}, \mathrm{S}=$ weight of oil sample, $\mathrm{N}=$ normality of sodium thiosulphate.

\section{Sensory evaluation}

The carcasses were cut into pieces and cooked with similar time, temperature and ingredients at day one of the experimental period. The cooked commercial broiler and indigenous chicken meat products were evaluated by six highly trained personnel. Sensory scores were nine for like extremely, eight for like very much, seven for like moderately, six for like slightly, five for neither like nor dislike, four for dislike slightly, three for dislike moderately, two for dislike very much, one for dislike extremely.

\section{Statistical analysis}

Data were analysed using analysis of variance procedure of $2 \times 3$ factorial design of two different sources of meat and three different storage times. The sensory evaluation data were analysed by $t$-test (SAS, 2002).

\section{Results and Discussion}

Effects of 30 days cold storage $\left(-20^{\circ} \mathrm{C}\right)$ on meat yield parameters of commercial broiler and indigenous chicken meat at one $\mathrm{kg}$ standard live weight is shown in Table 1. Carcass weight, dressing and breast meat yield as a percentage of live weight were significantly $(\mathrm{P}<0.05)$ higher in commercial broiler, however head, neck, thigh meat and drumstick meat as a percentage of live weight were significantly $(\mathrm{P}<0.01)$ higher in indigenous chicken. Our result agrees with Sandercock et al. (2009) that fastgrowing broiler has more breast meat than traditional chickens. The carcass yield of 
four breeds of local chicken was slightly lower than that reported for Italian local chickens (Marchi et al., 2005) and Benin local chickens (Youssao et al., 2012), and markedly lower than that reported for commercial broilers (Zhang et al., 2010; Panda et al., 2010). Nielsen et al. (2003) reported that slow-growing chickens were characterized by a lower breast yield, but higher yield of thigh and drumstick meatthan fast-growing chickens. These results are similar to this present study.

Table 1: Effects of 30 days cold storage period on meat yield parameters of commercial broiler and indigenous chicken meat at $1 \mathrm{~kg}$ live weight

\begin{tabular}{|c|c|c|c|c|c|c|}
\hline \multirow[t]{2}{*}{ Meat yield parameters } & \multicolumn{3}{|c|}{ Commercial broiler } & \multicolumn{3}{|c|}{ Indigenous chicken } \\
\hline & 0 day & 15 days & 30 days & 0 day & 15 days & 30 days \\
\hline Carcass weight \% & $63.7 \pm 1.3$ & $61.4 \pm 1.3$ & $60.4 \pm 1.0$ & $59.3 \pm 0.6$ & $56.6 \pm 1.2$ & $55.7 \pm 0.4$ \\
\hline Dressing \% & $60.8 \pm 1.1$ & $59.6 \pm 1.0$ & $58.5 \pm 1.0$ & $57.2 \pm 0.6$ & $53.4 \pm 1.1$ & $52.5 \pm 0.3$ \\
\hline Head weight\% & $3.2 \pm 0.2$ & $3.1 \pm 0.1$ & $2.9 \pm 0.1$ & $3.7 \pm 0.1$ & $3.6 \pm 0.1$ & $3.4 \pm 0.1$ \\
\hline Neck weight\% & $2.3 \pm 0.1$ & $2.2 \pm 0.1$ & $2.1 \pm 0.1$ & $3.2 \pm 0.2$ & $3.0 \pm 0.1$ & $2.8 \pm 0.1$ \\
\hline Breast meat (2)\% & $10.2 \pm 1.0$ & $10.0 \pm 1.0$ & $9.8 \pm 1.1$ & $7.6 \pm 0.1$ & $7.4 \pm 0.2$ & $7.2 \pm 0.1$ \\
\hline Shank weight (2)\% & $4.5 \pm 0.1$ & $4.4 \pm 0.1$ & $4.2 \pm 0.1$ & $3.1 \pm 0.1$ & $3.0 \pm 0.1$ & $2.8 \pm 0.1$ \\
\hline Thigh meat (2)\% & $5.7 \pm 0.3$ & $5.6 \pm 0.4$ & $5.4 \pm 0.4$ & $7.4 \pm 0.3$ & $7.2 \pm 0.40$ & $7.0 \pm 0.4$ \\
\hline Drumstick meat (2)\% & $4.4 \pm 0.5$ & $4.3 \pm 0.5$ & $4.2 \pm 0.5$ & $5.7 \pm 0.2$ & $5.5 \pm 0.22$ & $5.3 \pm 0.2$ \\
\hline Level of significance & \multicolumn{2}{|c|}{ Meat type } & \multicolumn{2}{|c|}{ Storage period } & \multicolumn{2}{|c|}{$\begin{array}{c}\text { Meat type* } \\
\text { Storage period }\end{array}$} \\
\hline Carcass weight & \multicolumn{2}{|c|}{0.0236} & \multicolumn{2}{|c|}{0.2070} & \multicolumn{2}{|c|}{0.9684} \\
\hline Dressing & \multicolumn{2}{|c|}{0.0144} & \multicolumn{2}{|c|}{0.5215} & \multicolumn{2}{|c|}{0.9026} \\
\hline Head weight & \multicolumn{2}{|c|}{0.0004} & \multicolumn{2}{|c|}{0.0744} & \multicolumn{2}{|c|}{0.9917} \\
\hline Neck weight & \multicolumn{2}{|c|}{$<.0001$} & \multicolumn{2}{|c|}{0.0925} & \multicolumn{2}{|c|}{0.8918} \\
\hline Breast meat & \multicolumn{2}{|c|}{0.0009} & \multicolumn{2}{|c|}{0.8725} & \multicolumn{2}{|c|}{0.9999} \\
\hline Shank weight & \multicolumn{2}{|c|}{$<.0001$} & \multicolumn{2}{|c|}{0.0065} & \multicolumn{2}{|c|}{0.9481} \\
\hline Thigh meat & \multicolumn{2}{|c|}{$<.0001$} & \multicolumn{2}{|c|}{0.5973} & \multicolumn{2}{|c|}{0.9852} \\
\hline Drumstick meat & \multicolumn{2}{|c|}{0.0025} & \multicolumn{2}{|c|}{0.7163} & \multicolumn{2}{|c|}{0.9738} \\
\hline
\end{tabular}

The $\mathrm{pH}$ of meat decreased with increased storage time $(\mathrm{P}<0.0096)$.

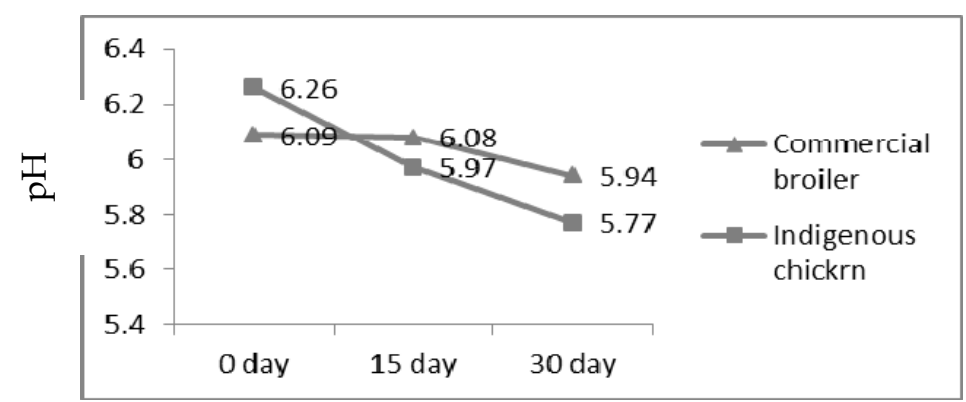

Storage time

Fig. 1: The pH of commercial broiler and Indigenous chicken breast meat. 
Dry matter content was higher in indigenous chicken breast meat than in commercial broiler breast meat $(\mathrm{P}<0.0001$, Table 2$)$. The dry matter content increased significantly $(\mathrm{P}<0.001)$ with time of storage. Indigenous chicken breast meat had significantly higher $\mathrm{CP}(\mathrm{P}<0.0004)$ than commercial broiler breast meat (Table 2). The CP content decreased significantly $(\mathrm{P}<0.0001)$ with storage time. According to Fletcher $(2002)$, differences in DM content and juiciness of meat, may be due to greater activity of freerange birds thanindoor chickens. The $\mathrm{CP}$ values were within the range 22.5 to $22.6 \%$ reported in broilers by Suchy et al. (2002) and 23.6 to $24.8 \%$ in indigenous Thai chickens by Jaturasitha et al. (2008). Sirri et al. (2010) reported that the protein content of slow-growing chickens was $24.6 \%$. Fanatico et al. (2007) found that the slowgrowing birds had higher protein content than the fast-growing ones. All these results are consistent with this study.

Table 2: DM and CP (\%) of Commercial broiler and indigenous chicken breast meat during 30 days cold storage

\begin{tabular}{|c|c|c|c|c|c|c|}
\hline \multicolumn{7}{|c|}{ Proximate composition (\%) } \\
\hline \multirow[t]{2}{*}{ Source of meat } & \multicolumn{3}{|c|}{$\mathrm{DM}$} & \multicolumn{3}{|c|}{$\mathrm{CP}$} \\
\hline & 0 day & 15 days & 30 days & 0 day & 15 days & 30 days \\
\hline Commercial broiler & $26.7 \pm 0.2$ & $26.7 \pm 0.3$ & $27.6 \pm 0.3$ & $23.2 \pm 0.4$ & $22.4 \pm 0.3$ & $20.6 \pm 0.3$ \\
\hline Indigenous chicken & $27.2 \pm 0.3$ & $27.6 \pm 0.4$ & $28.8 \pm 0.3$ & $24.4 \pm 0.1$ & $23.1 \pm 0.3$ & $22.4 \pm 0.4$ \\
\hline Level of significance & \multicolumn{2}{|c|}{ Meat type } & \multicolumn{2}{|c|}{ Storage period } & \multicolumn{2}{|c|}{$\begin{array}{c}\text { Meat type* } \\
\text { Storage period }\end{array}$} \\
\hline$\overline{\mathrm{DM}}$ & \multicolumn{2}{|c|}{$<.0001$} & \multicolumn{2}{|c|}{0.0018} & \multicolumn{2}{|c|}{0.1678} \\
\hline $\mathrm{CP}$ & \multicolumn{2}{|c|}{0.0004} & \multicolumn{2}{|c|}{$<.0001$} & \multicolumn{2}{|c|}{0.2008} \\
\hline
\end{tabular}

EE and total ash percentage were significantly $(\mathrm{P}<0.01)$ higher in commercial broiler breast meat than indigenous chicken breast meat (Table 3). Longeran et al. (2003) found higher lipid content of breast meat without skin from fast-growing broilers than slow-growing ones. Thai-indigenous breed meat contained lower fat and ash contents when compared to broiler meat (Wattanachant et al., 2004). These results are in agreement with the present study.

Table 3: EE and ash (\%) of commercial broiler and Indigenous chicken breast meat during 30 days cold storage

\begin{tabular}{|c|c|c|c|c|c|c|}
\hline \multicolumn{7}{|c|}{ Proximate composition (\%) } \\
\hline \multirow[t]{2}{*}{ Source of meat } & \multicolumn{3}{|c|}{$\mathrm{EE}$} & \multicolumn{3}{|c|}{ Ash } \\
\hline & 0 day & 15 days & 30 days & 0 day & 15 days & 30 days \\
\hline Commercial broiler & $1.5 \pm 0.1$ & $2.5 \pm 0.1$ & $3.0 \pm 0.1$ & $1.3 \pm 0.0$ & $1.3 \pm 0.0$ & $1.6 \pm 0.0$ \\
\hline Indigenous chicken & $1.1 \pm 0.1$ & $1.3 \pm 0.0$ & $1.4 \pm 0.0$ & $1.2 \pm 0.0$ & $1.3 \pm 0.0$ & $1.4 \pm 0.0$ \\
\hline Level of significance & \multicolumn{2}{|c|}{ Meat type } & \multicolumn{2}{|c|}{ Storage period } & \multicolumn{2}{|c|}{$\begin{array}{c}\text { Meat type* } \\
\text { Storage period }\end{array}$} \\
\hline $\mathrm{EE}$ & \multicolumn{2}{|c|}{$<.0001$} & \multicolumn{2}{|c|}{$<.0001$} & \multicolumn{2}{|c|}{$<.0001$} \\
\hline Ash & \multicolumn{2}{|c|}{0.0004} & \multicolumn{2}{|c|}{$<.0001$} & \multicolumn{2}{|c|}{0.0011} \\
\hline
\end{tabular}


Cooking loss was significantly higher in broiler meat than indigenous chicken meat $(\mathrm{P}<0.001$ Table 4). With increasing storage time, cooking loss of both types of chicken meat decreased significantly $(\mathrm{P}<0.001)$. Jaturasitha et al. (2002) found that the cooking loss of Thai native chicken was lower than commercial broiler chicken.

Table 4: The cooking loss (\%) characteristics of commercial broiler and Indigenous chicken breast meat during 30 days cold storage

\begin{tabular}{l|ccc}
\hline \multicolumn{4}{c}{ Cooking loss \% } \\
\hline \multicolumn{1}{c}{ Source of meat } & \multicolumn{3}{c}{ Storage period } \\
\cline { 2 - 4 } & $\mathbf{0 ~ d a y}$ & $\mathbf{1 5}$ days & $\mathbf{3 0}$ days \\
\hline Commercial broiler & $1.5 \pm 0.1$ & $2.5 \pm 0.1$ & $3.0 \pm 0.1$ \\
Indigenous chicken & $1.1 \pm 0.1$ & $1.3 \pm 0.0$ & $1.4 \pm 0.0$ \\
\hline Level of significance & Meat type & Storage period & Meat type \\
& & & Storage period \\
\hline Cooking loss & $<.0001$ & 0.0011 & 0.7640 \\
\hline
\end{tabular}

The TBARS value (mg malonaldehyde/ $\mathrm{kg}$ sample) increased with increasing storage time in both commercial broiler and indigenous chicken breast meat (Fig. 2) The TBARS values were significantly $(\mathrm{P}<0.0009)$ higher in commercial broiler breast than indigenous chicken breast over the whole storage time. It is normally accepted that with increasing storage time TBARS value increases. TBARS valued increased with increased storage period $(\mathrm{P}<0.0001)$.



Fig. 2: The TBARS values of commercial broiler and Indigenous chicken breast meat.

The oxidative status of breast meat evaluated as TBARS level was different in different genetic strains and a higher TBARS value was recorded with storage time in broilers (Castellini et al., 2006). Russell et al. (2003) found a higher TBARS value in duck breast meat with increasing storage time. Pettersen et al. (2004) found that TBARS value increased up to six months in refrigerated turkey breast meat and then declined. 
The FFA value increased significantly ( $\mathrm{P}<0.05$ from 0 to 30 days. The FFA values were significantly $(\mathrm{P}<0.0002)$ higher in commercial broiler breast than indigenous chicken breast over the whole storage time.



Storage time

Fig. 3: The FFA (\%) values of commercial broiler and Indigenous chicken breast meat.

Lipid peroxidation reflects the interaction between oxygen and polyunsaturated fatty acids (Verma et al., 2009). It occurs during processing and storage when meat is exposed to oxygen, heat, and light (Fasseas et al., 2007).



Storage time

Fig. 4: The POV values of commercial broiler and indigenous chicken breast meat.

POV (meq/kg) values (Fig. 4). were significantly higher $(\mathrm{P}<0.0075)$ in indigenous chicken meats than commercial chicken meat. The POV (meq/ $\mathrm{kg}$ ) value increased significantly $(\mathrm{P}<0.0004)$ with storage period. Rhee and Myers (2003) reported a similar trend in peroxide value in meat loaf made from ground goat meat during storage.

Colour, flavour and overall acceptability were not different between commercial broiler chicken and indigenous chicken; however, tenderness and juiciness were significantly $(\mathrm{P}<0.0219)$ higher in commercial broiler meat. 
Table 5: Sensory evaluation of commercial broiler and indigenous chicken meat product at $30^{\text {th }}$ day of cold storage

\begin{tabular}{l|cc|c}
\hline \multirow{1}{*}{ Parameters } & \multicolumn{2}{|c|}{ Treatments } & $\begin{array}{c}\text { Level of } \\
\text { significance }\end{array}$ \\
\cline { 2 - 3 } & Commercial broiler & Indigenous chicken & 0.2897 \\
Colour & $7.3 \pm 0.2$ & $7.7 \pm 0.2$ & 0.2897 \\
Flavour & $7.2 \pm 0.2$ & $7.6 \pm 0.2$ & 0.0394 \\
Tenderness & $7.8 \pm 0.24$ & $7.2 \pm 0.3$ & 0.0219 \\
Juiciness & $7.5 \pm 0.3$ & $6.7 \pm 0.2$ & 0.5995 \\
Overall acceptability & $7.5 \pm 0.3$ & $7.7 \pm 0.2$ & \\
\hline
\end{tabular}

\section{Conclusions}

Carcass weight, shank weight, dressing, breast meat yield were higher relative to live weight in commercial broiler, but head, neck, thigh meat, drumstick meat were higher in indigenous chicken, during 30 days of refrigeration. The higher TBARS value in commercial broiler breast meat indicates higher oxidative metabolism. It might be concluded that indigenous chicken meat has a lower rate of deterioration than that broiler when refrigerated.

\section{Acknowledgements}

This study was conducted with the financial support of Bangladesh Agricultural University Research System (BAURES, 2016/23/AU-GC).

\section{References}

AOAC 2005: Official methods of analysis (18 thedn) Association of official Analytical, Chemists international, Maryland, USA.

Castellini C, Bosco AD, Mugnai C, Pedrezzoli M 2006: Comparison of two chicken genotypes organically reared: oxidative stability and other qualitative traits of the meat. Italian Journal of Animal Science 5 29-42.

Decker EA, Chan WKM, Livisay SA, Butterfield DA, Faustman C 1995: Interactions between carnosine and the different redox states of myoglobin. Journal of Food Science $601201-1204$.

Fanatico AC, Pillai PB, Emmert JL, Owens CM 2007: Meat quality of slow-andfastgrowing chicken genotypes fed low-nutrient or standard diets and raised indoors or without door access. Poultry Science 86 2245-2255.

Fasseas MK, Mountzouris CK, Tarantilis PA, Polissiou M, Zervas G 2007: Antioxidant activity in meat treated with or egano and sageessentialoils. Food Chemistry 106 11881194.

Fletcher DL 2002: Poultry meat quality. World's Poultry Science Journal 58 131-145. 
Islam MA, Nishibori M 2009: Indigenous naked neck chicken: a valuable genetic resource for Bangladesh. World's Poultry Science Journal 5 125-138.

Jaturasitha S, Kayan A, Michael W 2008: Carcass and meat characteristics of male chickens between Thai indigenous compared with improved layer breeds and their crossbred. Arch Tierz Dummerstorf 51 283-294.

Jaturasitha S, Leangwunta V, Leotaragul A, Phongphaew A, Apichartstrungkoon A, Simasathitkul N, Vearasilp T, Worachai L, terMeulen U 2002: A comparative study of Thai native chicken and broiler on productive performance, carcass and meat quality. Proceeding of conference on International Agricultural Research for Development; October 9-11, Witzenhausen, Germany.

Lonergan SM, Deeb N, Fedlet CA, Lamont SJ 2003: Breast meat quality and composition in unique chicken populations. Poultry Science 2 1990-1994.

Marchi MD, Cassandro M, Lunardi E, Baldan G, Siegel PB 2005: Carcass characteristics and qualitative meat traits of the Padovana breed of chicken. International Journal of Poultry Science 4 233-238.

Mendes AA, Garcia EA, Gorzales E, Politi S 1994: Effect of strain on carcass yield in broilers. Poultry Abstract 20103.

Nielsen BL, Thomsen MG, Rensen PS, Young JF 2003: Feed and strain effects on the use of outdoor areas by broilers. British Poultry Science $\mathbf{4 4}$ 161-169.

Panda AK, Raju M, Rao SR, Lavanya G, Reddy EPK, Sunder GS 2010: Replacement of normal maize with quality protein maize on performance, immune response and carcass characteristics of broiler chickens. Asian Australasian Journal of Animal Sciences 23 1626-1631.

Pettersen MK, Mielnik MB, Eie T, Skrede G, Nilsson A 2004: Lipid oxidation in frozen, mechanically deboned turkey meat as affected by packaging and storage conditions. Poultry Science 83 1240-1248.

Rhee KS, Myers CE 2003: Sensory properties and lipid oxidation in aerobically refrigerated cooked ground goat meat. Meat Science 66 189-194.

Russell EA, Lynch A, Galvin K, Lynch PB, Kerry JP 2003: Quality of raw, frozen and cooked duck meat as affected by dietary fat and a-tocopheryl acetate supplementation. International Journal of Poultry Science 2 324-334.

Rukunudin IH, White PJ, Bern CJ, Bailey TB 1998: A modified method for determining free fatty acids from small soybeans amplesizes. Journal of American Oil Chemistry Society 75 563-568.

Sandercock DA, Nute GR, Hocking PM 2009: Quantifying the effects of genetic selection and genetic variation for body size, carcass composition, and meat quality in the domestic fowl (Gallus domesticus). Poultry Science 88 923-931.

SAS 2002: SAS Softwear for PC. SAS Institute Inc., Cary, NC, USA. 
Schmedes A, Holmer G 1989: A new thiobarbituric acid (TBA) method for determining free malondialdehyde (MDA) and hydroperoxides selectively as a measure of lipid per oxidation. Journal of American Oil Chemistry Society 66 813-817.

Sirri F, Castellini C, Roncarati A, Franchini A, Meluzzi A 2010: Effect of feeding and genotype on the lipid profile of organic chicken meat. European Journal of Lipid Science and Technology 112 994-1002.

Suchy P, Jelinek P, Strakova E and Hucl J 2002: Chemical composition of meats of hybrid Broiler chickens during prolonged feeding. Czech Journal of Animal Science 47 511-518.

Symeon GK, Mantis F, Kominakis AB, Rogdakis E 2010: Effects of caponization on growth performance, carcass composition, and meat quality of medium growth broilers. Poultry Science 89 1481-1489.

Verma AR, Vijayakumar M, Mathela C, Rao CV 2009: In-vitro and in-vivo antioxidant properties of different fractions of Moringa oleifera leaves. Food and Chemical Toxicology 47 2196-2201.

Wattanachant S, Benjakul S, Ledward DA, 2004: Composition, color, and texture of Thai indigenous and broiler chicken muscles. Poultry Science 83 123-128.

Youssao IAK, Alkoiret IT, Dahouda M, Assogba MN, Idrissou ND, Kayang BB, Gnaore VY, Assogba HM, Houinsou AS, Ahounou SG 2012: Comparison of growth performance, carcass characteristics and meat quality of Benin indigenous chickens and Label Rouge (T55×SA51). African Journal of Biotechnology 111 5569-15579.

Zhang Y, Ma Q, Bai X, ZhaoL, Wang Q, Jic, LiuL, Yin H 2010: Effect of dietary acetyl-Lcarnitine on meat quality and lipid metabolism in Arbor Acres broilers. AsianAustralasian Journal of Animal Sciences 23 16 39-1644. 